
religious people majority in Indonesia. International Journal of Social Sciences, 4(1), 106-113.

\title{
Regulation on Worship House Establishment and Implication towards Minority Relation of Religious People Majority in Indonesia
}

\author{
Arifinsyah \\ Lecturer at the Faculty of Ushuluddin and Islamic Studies State Islamic University of North Sumatra, Indonesia \\ Corresponding author email: arifinsyah@uinsu.ac.id
}

\author{
Ahmad Sofian \\ Ministry of Religion of Batu Bara Regency, Indonesia \\ Email: ahmadsofianbatubara@gmail.com
}

\begin{abstract}
This study aims to determine the implications of regulations for building houses of worship for minority relations of most religious communities in Indonesia. Several studies have examined the implications of regulations regarding establishing places of worship for the relations of the majority of religious communities in Indonesia. The regulation appears to make it difficult for religious minorities to build houses of worship. This regulation has implications for religious disharmony and disruption of national unity and integrity. It is time for regulations related to development to be reviewed and refined so that relations between minority communities and majority religions can be adequately maintained, said the study. This research uses a qualitative approach. It is time for regulations related to the construction of places of worship to be reviewed and refined so that relations between minorities and the majority of religious communities in Indonesia are well maintained.
\end{abstract}

Keywords---harmony, worship house, majority minority, regulation.

\section{Introduction}

The establishment of places of worship is a fundamental need for religious people. However, for minority communities it is not easy to establish it, because it is related to the applicable regulations in a country. In Indonesia, to regulate the harmony of religious communities and the ability to build houses of worship as stipulated in PBM No.9 and 8 of 2006. It turns out that this regulation raises various implications for the minority relations of the majority of religious communities in an area. For religious people whose adherents are the majority, perhaps it is not difficult to build a house of worship according to the applicable regulations. However, religious people who adhere to a minority in an area often face various obstacles and difficulties in establishing their houses of worship. Why does this happen, even though a house of worship is a basic need for religious people. This can occur due to several factors, including religious sentiment factors, religious insight factors of regional leaders who are less able to understand the heterogeneity of the constellation, and do not rule out the implication of the rules or legislation in force.

In Indonesia, the government has issued regulations on the construction of places of worship and religious broadcasting. In 1969 the government issued a Joint Decree of the Minister of Religion and the Minister of Home Affairs No. 01 / Ber / mdn-mag / 1969 concerning the implementation of the duties of the government apparatus in ensuring order and the smooth implementation of religious worship and development by its adherents. The joint decree also regulates the construction of places of worship, as well as the requirements for the number of congregation members who should own places of worship. The decree certainly did not appear suddenly, there was a socio-religious context that encouraged it and could not be separated from the contestation of the religious community. 
In 2006 the government again issued a regulation on the construction of places of worship, namely the Joint Regulation of the Minister of Home Affairs and the Minister of Religion No. 9 and 8 of 2006. The regulation regulates three interrelated matters, namely the obligation of the Regional Government to preserve harmony, the establishment of the Forum for Religious Harmony as a forum for fostering religious harmony, and regulations on procedures for establishing places of worship. Articles 13-17 of the Joint Regulation state that the construction of places of worship must meet the administrative and technical requirements of buildings, and have the support of 90 people and 60 users (Lubis, 2017; Carter et al., 2012). If these requirements are not met, then houses of worship may not be built, this is a problem of minority relations for the majority of the local community. The diversity of races, ethnic groups, cultures and religions in Indonesia, of course, is not easy for the government to maintain harmony (RI Ministry of Religion, 2014). All religions and beliefs in Indonesia have their respective places of worship as places of worship and empowerment of the people. This is guaranteed by the State as stipulated in the 1945 Constitution article 29 and article 28 (e) paragraphs 1 and 2 that everyone is free to embrace a religion and worship according to their religion, and has the right to freedom of belief, expressing thoughts and attitudes, in accordance with conscience. This is confirmed again in Law no. 39 of 1999 that everyone is free to embrace their respective religions and to worship according to their religion and beliefs. Article 8 also emphasizes that the protection, advancement, enforcement and fulfillment of human rights are the responsibility of the State and the government (Suaedy et al., 2007).

The existence of regulations on the construction of places of worship has not guaranteed harmony and order in the construction of places of worship. Not a few people due to regulatory reasons, a number of houses of worship were forced to close, causing tension, anger, vandalism and arson. In 1999 there was an act of burning the Al-Ikhwan Muslim mosque in Poso Pesisir by a group of unknown people. Muslim residents in Ambon were attacked by brutal mobs. Dozens of people were killed, hundreds were injured. Several Muslim settlements were leveled to the ground. Meanwhile, dozens of mosques were destroyed. Markets, shops, people's houses, as well as dozens of public transportation and hundreds of rickshaws belonging to Muslims were burned (Republika, March 7, 1999). On April 10, 2012, the Bogor City Government sealed the GKI Yasmin because the GKI Yasmin ignored their warning regarding the construction of the church. In 2001 and 2015 in Aceh Singkil District there were conflicts over the construction of places of worship, leading to acts of anarchism and the destruction of places of worship by certain groups.

In 2018, the Association of Churches in Jayapura Regency (PGGJ) rejected the renovation of the Al-Aqsa Grand Mosque in Sentani, Papua. The reason is that the mosque's minaret is taller than the nearby church on Jalan Raya Abepura. Conflicts over places of worship continue to occur and their numbers are increasing. This fact can be seen from various data released by a number of institutions. According to the records of the Center for Religious and Cross-cultural Studies (CRCS) of Gadjah Mada University, in 2008 there were at least 12 cases of conflict around houses of worship. Meanwhile in 2009 there were 18 cases and in 2010 there were 39 cases. It seems that the dynamics of conflict in cases of building houses of worship have increased from year to year, including in 2016 the destruction of houses of worship in Tanjung Balai City, North Sumatra. The symbolic conflict between Islam and Buddhism in the case of the Amithaba Statue found its climax when an ethnic Chinese was deemed to have insulted the call to prayer at the mosque.In 2010 there was a rejection of the construction of the al-Munawarah Sarulla mosque in Pahae Jae District, North Tapanuli Regency, until now the mosque has not been able to be built. The permit to build a mosque building was not issued by the local government to this day, but Muslims are not anarchists and are still waiting for that permission. For various reasons that are irrational and unconstitutional, the local government still does not give permission. One year later, on March 30, 2011, two mosques were burned in Aek Loba Village, Aek Kuasan District, Asahan Regency. This reality shows that the implementation of regulations on the construction of places of worship is still not running well, there are still many religious people from minority groups in an area who have difficulty getting access to the construction of places of worship. Intolerance and conflicts between religious believers that have been triggered by regulations on the construction of places of worship in the last decade are quite concerning.

Historical facts prove that so far religions have tended to be the driving force for violence in the name of faith because it is triggered by the nature of absolutism (truth claim) or one-sided truth (Kimball, 2008; Cohen et al., 2008). Religion can exist as a source of "conflict" and "divider" not in its divine realm. Normatively, religions state that their teachings do not contain elements of conflict or elements of division. His appeal is peace and well-being, even though traditional religious systems claim absolute devotion. Each claims to be a monopolist on the saving power, although this kind of exclusive claim is sometimes necessary and seen as a natural instrument for the selfidentification of a group against the claims of others to absolute truth. On this basis, not many have dared to adopt 
religious teachings, including the construction of places of worship, as a trigger for conflict. The application of regulations on the construction of places of worship will be more complex if it is linked to other ideologies.

The reality of the conflicts that are rife in Indonesia at least proves Schimmel's thesis that in addition to functioning as a social unifying tool, religion can also become an elements of conflict. These two elements are united in religion, like two sides of the same coin in cohesion and consensus (Venkataraman, 2007; Sedikides \& Gebauer, 2020). This is where the mission of religion, if not expressed in accordance with the claim of its spirituality that brings peace and foster brotherhood, will become a trigger for conflict. When religion has fused with other aspects of life, it is not uncommon for religion to become a means of legitimizing violence. To spark violence, individual religious identities must be homogenizedcommunal. Religion will be a powerful force in generating religious emotional identity compared to other social identities. It is in this context that Kakar's analysis that religion brings conflict between groups with greater emotional intensity and a deeper coercive motivation than language, region, or ridicule against other ethnic identities, finds its relevance (Kakar, 1996; Ellis \& Biglione, 2000). At this point, it is interesting to examine in more depth the urgency of the regulation on the establishment of places of worship and what the implications are for minority relations of the majority of religious communities in Indonesia.

\section{Research Methods}

This study uses a qualitative approach by exploring contemporary matters. This study aims to explore the implications of regulations on the construction of places of worship for the majority of minority relations in Indonesia in the last five years. Data mining was carried out through observation, interviews, and literature review. Observations were made of the community around the construction of problematic houses of worship. Interviews were conducted with a number of key informants, namely religious leaders, community leaders, and the government in Aceh province representing the majority of Muslims, and North Sumatra province representing non-Muslim minorities. Meanwhile, literature review is carried out to extract information carried out on a number of books, research reports, and documents that are relevant and related to the research theme.

The participants of this study were 5 Islamic religious leaders, both as mosque administrators and religious teachers, and 5 pastors and church administrators. 5 community leaders were also used as participants and informants, and 5 people represented the government in each research sample. Participants were determined by selecting participants who were in accordance with the demographics of the study and stated that they were willing to provide the data needed in this study.

Data collection was carried out in two ways, the first was a Focus Group Discussion (FGD) using the Whatshapp Group (WAG) to collect demographics and initial interviews regarding regulations on the establishment of inadah houses and their implications for minority-majority relations. The FGD was followed by in-depth interviews with all participants which were conducted individually. Interviews were conducted in person while still using health protocols. Interviews were conducted in-depth recorded. Interviews were conducted with open-ended questions so that participants can use their own language to reveal things that have not been conveyed in the FGD (Leavy, 2017). In-depth interviews were conducted by the researcher himself and assisted by technical staff to record and transcribe the interview.

Data analysis was carried out through data reduction, namely selecting relevant data with research subjects and suspending irrelevant data. Furthermore, the data that has been reduced are categorized based on the items in the study. Meanwhile, the FGD transcripts and in-depth interviews were processed using thematic analysis through six steps. (1) Familiarizing yourself with the data, in which the researcher reads the FGD transcripts and interviews over and over again to reveal the wealth of information from the data. (2) and (3) Generating initial codes, at this stage the researcher coded the data manually to find potential themes. (4) and (5) reviewing potential themes, Searching for themes, Defining, and naming themes, is done by reviewing potential themes, searching for, defining, and naming themes by reading repeatedly and deciding the main theme that arises from data. (6) write a report. The guarantee of the validity of the research data was carried out by means of member checks and triangulation. Member check is carried out by giving the interviewee the opportunity to comment on the research results in the form of a draft article (Ortiz \& Greene, 2007; Stavrova et al., 2013). This is done to compare the results of interviews between one participant and another on the same theme.Research Findings.

\section{Research Findings}

The minority referred to in this paper are: "Small group (as opposed to the majority); the situation is not large or not many, the group is small or very few. A social group whose number of citizens is much smaller when compared to 
other groups in a society and therefore, is discriminated against by that group. Minority comes from the word minority, which means a small group. While the majority is the largest number of people. The majority are social groups whose number of citizens is much larger and more numerous when compared to other groups in one society.

The majority and minority boundaries are sociological terms to refer to the quantity of individuals who come together in a unity. As a concept, or paradigm. This term is often used to build an analytical framework for the relationship between one group and another. In addition, the notions of minority and majority already contain political meaning, in which one refers to a large number of assemblages or meetings and meetings, and is generally supreme in many ways. While the other one refers to a collection or meetings of individuals that are less, which in quality cannot possibly be more supreme than the majority.

In a pluralistic society such as in Indonesia, religion can be a unifying factor for the nation and at the same time a trigger for conflict. Religious conflicts are more often than not the manipulation of social conflicts with religious symbols for specific purposes. In fact, there are many ways for religious people to live in harmony, peace and with positive tolerance, and can cooperate closely in social reform, both communally and institutionally. Conflicts that occur in various regions in Indonesia are not only born by religion and between religious communities, but also by the majority and minority adherents of a religion, including by conflicts between civilizations.

When researchers asked religious leaders and local government about what caused the inter-religious conflict, they answered:

The establishment of houses of worship is one of the factors in the emergence of conflicts between religious believers in Indonesia, many cases have occurred, such as in North Sumatra, for example there was an abuse of the permit to build a wooden panglong into the establishment of a Buddhist house of worship in Marelan Medan Labuhan, which led to conflict between Muslims and Muslims. Buddha. In fact, according to the statement of the Head of the Office of the Ministry of Religion of the Republic of Indonesia, Karo Regency, the establishment of houses of worship is one of the factors in the emergence of majority conflicts against minorities in North Sumatra.

Houses of worship are places for religious believers to express their faith in order to fulfill their spiritual needs for the Creator. Places of worship are considered as identity, image, honor, togetherness, greatness, and even pride. With this meaning, the place of worship was built with a large, magnificent and beautiful size at a fairly expensive cost. So it is not uncommon for religious gaps to occur in the construction of houses of worship that are established in the midst of followers of the majority religion who are not users of these places of worship. However, it was found that the construction of places of worship often experienced problems, because to build houses of worship in Indonesia must comply with regulations, namely Joint Ministerial Regulations number 9 and 8 of 2006. As happened in the provinces of North Sumatra and Aceh Provinces.

Aceh Province is the only province in Indonesia that is granted special rights in the fields of religion, education and customs. Such is the strong influence of Islam in the life of the Acehnese people, so that Islamic teachings in the fields of worship, marriage and inheritance have been carried out for a long time, from the previous sultanate to the present, so that they have become integrated with today's daily life which tends to be strictly adhered to (Al-Maliki, 2005). Socially, in Aceh there are not only Muslims but also non-Muslims who are a minority in number. The people of Aceh who adhere to this different religion, in their social life, must be in touch with Muslims. This contact has sometimes led to conflicts between religious believers and one district/city that is relatively frequent in this conflict is the district of Aceh Singkil. Aceh Singkil Regency which is directly adjacent to the province of North Sumatra. This has experienced conflicts between religious believers, especially conflicts over the construction of places of worship in 2015 , which resulted in property victims and even casualties.

The house of worship is one of the religious symbols that the people are proud of. This is what underlies why houses of worship should be established by adherents. For Muslims, mosques and mushalla are established in the community, both in residential areas, in work environments, and in shopping areas. For Christians from certain denominations, or for Catholics who agree on one church for all, as well as for other religions.

Ideally, the existence of a synagogue is a place for every religious person to get the nuance of a harmonious and peaceful life because the synagogue is the area of everyone's life to escape from the pressures of worldly life and get closer to God. However, in reality this is not the case. In fact, what happens is that the existence of houses of worship is a problem that is prone to disrupting harmony between religious communities in Indonesia. This is because the existence of a synagogue, in the perception of various parties, has not yet functioned to connect humans with their God. The main reason is that the existence of a house of worship cannot be separated from its connection with shortterm interests, including political interests (Ahmad, 2012).

The establishment of places of worship in the public sphere often creates problems that are peppered with conflicts of interest, namely disturbing the ideals of religious harmony in the context of nationality. Conflict over houses of worship involves collective action, including from parties questioning the establishment of houses of 
worship and involving the government as the target of the process or claim making as well as providing regulations related to the construction of houses of worship. In Aceh itself it was added with the Governor of Aceh Regulation, No. 25 of 2007 concerning Guidelines for the Construction of Houses of Worship.

The establishment of houses of worship is a source of vulnerability in inter-religious harmony. Houses of worship that are established without considering the situation and environmental conditions of the local religious community tend to create disharmony between religious believers. Meanwhile, religious harmony must always be maintained, both by the government and society. The vocabulary for maintaining religious harmony is one of the clauses that appear in the Joint Ministerial Regulation (PBM), as a sign that the government participates in maintaining religious harmony in Indonesia, especially in terms of the construction of houses of worship.

The inter-religious conflict in Aceh Singkil district that occurred in 2015, this conflict occurred on 13 October 2015 which was marked by the fall of casualties. Symptoms of this conflict can be seen from several previous incidents, including: first, that on 20 July 2015 FKUB held a meeting in order to increase tolerance and harmony in religious life in Aceh Singkil district. This meeting was attended by Forkopimda Aceh Singkil district whose conclusion was that the sub-district heads had to hold a meeting with all related elements, urged all parties to obey the existing rules in carrying out religious life activities and prioritize dialogue by involving religious and traditional leaders for harmony in life together. . Second, following up on the meeting, on August 132015 the FKUB team again conducted direct monitoring to the field to clarify the existence of a community report stating that a church construction had been banned and the result was correct that the church construction was still ongoing. (Forum for Religious Harmony (FKUB) Singkil Nangro District Aceh Darussslam, September 9, 2019).

The construction of a church that violated this rule was followed by a demonstration on 6 October 2015 by the Aceh Singkil Islamic youth group demanding that the Aceh Singkil district government close and demolish all churches that do not have a permit and be carried out within a seven period days from the submission of the claim. If these demands are not carried out by the government they will do so themselves. Responding to these demands, on 8 October 2015 the Aceh Singkil district government along with the FKUB, Dandim 0109 / Aceh Singkil and the Aceh Singkil Police Chief held a joint meeting and produced recommendations as material for consideration for the Aceh Singkil government in making policies.

The conflict over the construction of places of worship has implications for disharmony in the relations of the majority minority in Indonesia. Conflict between religious communities in Aceh Singkil district is related to the agreement of several churches that were founded. In other words, the inter-religious conflict in Aceh Singkil district was caused by the construction of a church that was without a permit and was in conflict with the existing qanuns in Aceh and the PBM regulations no.9 and 8 of 2006. It can be ascertained that the conflicts that have occurred so far stem from the establishment house of worship that is not in accordance with the existing provisions. The construction of houses of worship, especially the construction of churches, was out of control, which caused the emotions of Muslims to ignite because they felt that Christians had violated the existing regulations. The local government itself did not take a stand against church construction outside of these provisions, but this attention only came after protests from Muslims emerged.

The conflict in Aceh Singkil district was not a conflict with a background of SARA, but was motivated by an incomplete settlement of regulations on the construction of places of worship. Currently the problem is like a time bomb which was not defused but was left unfinished. The cause of the conflict here is because the government is not aware of religious activities or practices in the construction of houses of worship. This opinion is corroborated by other data sources which say that the conflict between Aceh Singkil religious communities has something to do with the agreement of several churches that were founded. In the Aceh Singkil district, the source of the conflict was the permit to build a house of worship, not a matter of religious teachings. Everything has been regulated, the number of users, how many supporters, and how many new places of worship can be built. The main cause of the conflict in Aceh Singkil district is the problem of building churches without a permit where non-Muslims build in accordance with the rules stipulated by the qanun. The government knows about the construction of this church, but does not pay attention to the existing regulations. So, this conflict occurred due to excessive church construction. (Result of interview with the Management of the Indonesian Church Fellowship (PGI) for the region of North Sumatra Province on September 15, 2019).

The implications of the regulation of the establishment of places of worship for minority and majority relations in North Sumatra Province are very concerning. The population in this province is estimated to reach $14,349,771$ people, also experiencing disharmony. This regional society is quite heterogeneous, both in terms of religion, ethnicity, ethnicity, race, and class groups. The most obvious impact caused by these minorities and the majority is the threats that come to ethnic minority groups causing them to have higher suspicion of others and they are also more closed in social interactions. The closure of minority groups in social interactions can reduce minority groups 
to associate intimately with the majority group. As a result, the minority and majority groups do not know each other well, so that it will have the potential to cause negative prejudice between them, which in turn has an unfavorable and disharmonious effect between them. In North Sumatra, the impact of this prejudice exists between the majority and minority ethnic groups, but it does not lead to mass conflict between those who are adherents of the majority and minority religions.

In addition to the prejudice caused by the impact of the majority and minority adherents of Islam and Christianity in North Sumatra, there are also other negative impacts arising from the majority against minorities, namely minorities usually have high distrust of the majority, and view the majority as prejudice and less communicative. Minority groups usually do it for real cooperation which requires them to be closely tied to the majority ethnic group. Cooperation that occurs between majority and minority groups is generally only open cooperation and does not require a commitment to safeguard certain secrets. This means that there is no genuine cooperation and mutual trust, trust, on the contrary, mutual suspicion.

In 2016 in the City of Tanjung Balai, North Sumatra, there was a conflict over places of worship and vandalism as well as the emergence of tensions that had not been resolved for more than 10 years. During the conflict, 11 temples and shrines were burned down by the masses. The Tanjungbalai City FKUB field notes and the results of the investigation by FKUB of North Sumatra Province explained that the persistence of symbolic conflicts between Islam and Buddhism in the Amithaba Statue case from 2010 to 2016 found its peak when an ethnic Chinese was deemed to have insulted one of the mosques. In Binjai City, it is also difficult to build a house of worship, for over 10 years the church has not been able to be built. This is due to tensions arising between local residents and church attendance which is deemed not fulfilling the requirements as stated in PBM no.9 and 8 of 2006. (Result of interview with the Management of the Forum for Religious Harmony (FKUB) in the City of Tanjung Balai, North Sumatra, on the 12th. October 2019).

In Deli Serdang Regency, bordering the city of Medan to be precise in Laut Dendang Village, a church had to be moved because when the widening was not carried out based on regulations, the surrounding community demanded that the church be moved. The conflict has been going on for 10 years. Burning of houses of worship and houses of Christians in Sibuhuan, Barumun District, Padang Lawas Regency which were used as houses of worship. Residents flocked to the location of the construction of houses of worship and a fire quickly broke out of one unit of the house of worship and two housing units of Christian residents, because it was not in accordance with the regulations. Likewise, the Munawarah Sarulla Mosque, Pahae Jae Subdistrict, North Tapanuli Regency, has not been established since 2010 until now. For various reasons that were irrational and unconstitutional, the local government still did not give permission, seemed to be vindictive and ignorant, this also triggered mass conflict.

The establishment of the al-Khairiyah mosque and the Raudhatul Islam mosque on Yos Sudarso Street, Silalas Village, West Medan. On the land area of the State, elite houses have been established. Not only do they control state assets, the land mafia also demolishes mosques. There is community unrest in Buntu Pane Village, Buntu Pane District, Asahan Regency because of the GKPS Church construction activity that does not meet administrative requirements.

Construction of the GBKP Church in Gung Pinto Village, Naman Teran District, Karo Regency. The residents object to the construction of the GBKP Church in Gung Pinto Village, Naman Teran District, Karo Regency. Construction of the Meitreya Jaya Temple in Tebing Kisaran Village, West Kisaran City District, Asahan Regency. The rejection letter from the MUI of Asahan Regency was due to the establishment of this Vihara near the Grand Kisaran Mosque. The Ministry of Religion of Asahan Regency has not yet issued a recommendation for the establishment of houses of worship. The house that was used as a house of worship for the GBI Antiokhia Church in the Tebing Indah Permai Housing Complex in Link. 02 Kelurahan Bandar Utama Kec. Tebing Kota, Tebing Tinggi. There were objections from the residents of the Housing Complex to the activities at the GBI Church in question. A medical center that functions as a Vihara in Tanjung Balai City. There were objections from the community due to the permit to build the building as a medical center but it was used as a house of worship.

The presence of a house of worship that does not comply with existing regulations, often becomes a source of conflict and disruption of relations between religious believers, or even triggers conflict because of its location in the middle of a community that mostly adheres to other religions. The house of worship in this connection is not only seen as a place to carry out worship or religious activities only, but also as a symbol of the existence of a religious group. The problem becomes complicated if the number of synagogues is viewed by other parties not based on necessity, but for the benefit of religious broadcasting in other communities. Cases related to the destruction of houses of worship became one of the factors behind the birth of the Decree of the Minister of Religion and the Minister of Home Affairs No. 1 of 1969 which was later refined and replaced with PBM No. 9 and 8 of 2006. (Result 
of interview with the Management of the Forum for Religious Harmony (FKUB) Tanjung Balai City-North Sumatra, October 13, 2019).

In fostering harmony between religious communities, there must be such a thing as a gap between one another. With regard to various social problems that contain the potential for conflict in the local community and can disrupt and harm various efforts to manifest religious harmony, for example, dwellings that function as houses of worship are found in most districts / cities which are the target of this study. This has generated a lot of protests, because it is seen as contrary to mutually agreed terms. Community protests have also emerged in several areas related to the establishment or presence of houses of worship which are deemed not in accordance with the prescribed procedures or requirements. These protests can cause turmoil to disrupt harmony.

Data obtained from the 2019 Religious Harmony Lounching Index, shows that North Sumatra is at a low score of harmony and harmony, and the lowest is Aceh province. Hate is a dominant factor, including hatred towards the establishment of places of worship which affects inter-religious harmony in Indonesia.

Building peace is a strategy or effort to try to restore the destructive state of violence that occurred in conflict by building a communication bridge between the parties involved in the conflict. The goal of peace building is not only limited to ending conflicts and maintaining peace agreements (Galtung, 2003).

However, this concept includes broad and comprehensive works both during the conflict and after the conflict. During conflict peace works are usually focused on conflict intervention through mediation or facilitation and reconciliation. The goal is to manage to localize the conflict so that it does not spread everywhere, and as much as possible to minimize it.

In this context, the importance of the role of religious leaders in providing the best solutions to the problems of building houses of worship in Indonesia. Even though the government has a state obligation to protect the rights to freedom of religion or belief of all citizens, the role of religious figures can be said to be much more significant. This is because religious leaders have a high position in society, especially in their religious community. They are respected as leaders and patrons of their religious community. Religious leaders can also function as conflict resolvers in case of tensions or conflicts, both within religious communities and between religious communities, which result from the realization of the right to freedom of religion.

For this reason, the regional government must also facilitate the role of these religious leaders, especially in forums that can become instruments to develop an understanding of the essence of freedom of religion or belief. The Religious Harmony Forum (FKUB), which is the mandate of the Joint Regulation of the Minister of Religion and the Minister of Home Affairs, needs to be empowered, not only as an agency that provides considerations for the establishment of houses of worship, but also as a medium for intensive dialogue and consultation between religious leaders. Then the results of the intensive dialogue and consultation are socialized to the people who are the responsibility of each religious leader. This is because the Forum for Religious Harmony (FKUB) is a forum that not only works to bridge the aspirations between the community and the government, but more than that, as a "vehicle" in order to accelerate the resolution of problems of religious communities in the field. The Forum for Religious Harmony (FKUB) is more required not only to focus on technical-administrative matters, but to think more about matters that concern many interests and broader matters including building various collaborations in empowering people who collapsed due to social inequality and various problems left by the conflict.

According to Hans Kung, the Pancasila applied in Indonesia with its religious concept is in accordance with the spirit of nationality and the cultural roots of the nation. This means that there is no survival without world culture and ethics, besides there must be a minimum consensus between believers and people who are not. Pancasila places adherents of religion and those who are not in the same position. This religious concept creates an equal humanity in accordance with what the Parliament of world religions means as the world's most basic need, because every human being must be treated humanely (Kng \& Kuschel, 1993). As a state ideology, Pancasila emphasizes the creation of harmony between religious believers.

In Indonesia, in an era of fully open democracy, the differences in views and interests among the very diverse citizens are managed in such a way that all aspirations can be channeled accordingly. Likewise in religion, the constitution guarantees the freedom of religious people in embracing and carrying out religious teachings in accordance with their respective beliefs and beliefs. Indonesia has even become an example for the nations of the world in terms of successfully managing its cultural and religious diversity, and is considered successful in harmonizing how to be religious and state. 


\section{Conclusion}

The regulation on the establishment of houses of worship has implications for religious minorities, namely the unfulfilled number of supporters and users. Meanwhile, places of worship are a need for religious communities as the existence of the religion they adhere to, and a human right that cannot be castrated by anyone. The regulation on the establishment of places of worship provides room for tensions in the relationship between the majority and minority. Many churches located in Muslim-majority areas have difficulty applying for an IMB, then the community rejects their activities. Likewise, it is difficult to build a mosque that is in a Christian-majority area in order to apply for an IMB. Not only has an impact on one group of religious communities, this regulation also has an impact on the disharmony of the majority minority relations in an area, and does not rule out the possibility of conflict. The low understanding of the apparatus and the community towards regulations and the limited religious insight of the local religious community has led to minority tyranny and majority domination which resulted in mass interfaith conflicts.

This regulation also has implications for disharmony between religious believers and disruption of national unity and integrity. Given the importance of preserving inter-religious harmony, it is time for the existing regulations to be reviewed and perfected, so that relations between religious believers are well-established. In fact, this regulation exists to provide tools for the government and society in preserving inter-religious harmony.

\section{Acknowledgments}

We, the authors, would like to thank all colleagues for their support of ideas and feedback on the work of this study from beginning to end. Likewise, to departments that have supported funding so that we can complete this study according to the objectives with very satisfying results.

\section{References}

Ahmad, H. A. (2012). Hubungan umat beragama: Studi kasus penutupan/perselisihan rumah ibadat. Kementerian Agama RI, Badan Litbang dan Diklat, Puslitbang Kehidupan Keagamaan.

Al-Maliki, A. (2005). Abdullah, Taufik ed., Agama dan Perubahan Sosial (CV. Rajawali 1983). Abubakar, Alyasa', Syariat Islam di provinsi Nangroe Aceh Darussalam, Paradigma Kebijakan dan Kegiatan 59 (Banda Aceh, Islamic law services of Nangroe Aceh Darussalam province 2005).

Carter, E. C., McCullough, M. E., Kim-Spoon, J., Corrales, C., \& Blake, A. (2012). Religious people discount the future less. Evolution and Human Behavior, 33(3), 224-231. https://doi.org/10.1016/j.evolhumbehav.2011.09.006

Cohen, A. B., Shariff, A. F., \& Hill, P. C. (2008). The accessibility of religious beliefs. Journal of Research in Personality, 42(6), 1408-1417. https://doi.org/10.1016/j.jrp.2008.06.001

Ellis, L., \& Biglione, D. (2000). Religiosity and obesity: are overweight people more religious?. Personality and Individual Differences, 28(6), 1119-1123. https://doi.org/10.1016/S0191-8869(99)00161-0

Galtung, J. (2003). Studi Perdamaian: Perdamaian dan Konflik, Pembangunan dan Peradaban. Pustaka Eureka.

Kakar, S. (1996). The colors of violence: Cultural identities, religion, and conflict. University of Chicago Press.

Kimball, C. (2008). When religion becomes evil. HarperOne New York, NY.

Kng, H., \& Kuschel, K.-J. (1993). Global Ethic: The Declaration of the Parliament of the World's Religions. Bloomsbury Publishing.

Leavy, P. (2017). Research design: Quantitative, qualitative, mixed methods, arts-based, and community-based participatory research approaches.

Lubis, R. (2017). Analisis Pengembangan Kompetensi Penyuluh Agama Pada Ditjen Bimas Islam Kementerian Agama Republik Indonesia Dalam Memelihara Kerukunan Umat Beragama.

Ortiz, D., \& Greene, J. (2007). Research design: Qualitative, quantitative, and mixed methods approaches. Qualitative Research Journal, 6(2), 205-208.

Sedikides, C., \& Gebauer, J. E. (2020). Do religious people self-enhance?. Current Opinion in Psychology. https://doi.org/10.1016/j.copsyc.2020.08.002

Stavrova, O., Fetchenhauer, D., \& Schlösser, T. (2013). Why are religious people happy? The effect of the social norm of religiosity across countries. Social science research, 42(1), 90-105. https://doi.org/10.1016/j.ssresearch.2012.07.002

Suaedy, A., Rumadi, \& Suaedy, A. (2007). Politisasi agama dan konflik komunal: Beberapa isu penting di Indonesia. Wahid Institute.

Venkataraman, A. (2007). Understanding How Religion Becomes Evil. Strategic Analysis, 31(1), $193-201$. 